\title{
Thyroid crisis caused by metastatic thyroid cancer: an autopsy case report
}

\author{
Kai Takedani ${ }^{1}$, Masakazu Notsu ${ }^{1 *}$ D, Naoko Adachi ${ }^{1}$, Sayuri Tanaka ${ }^{1}$, Masahiro Yamamoto ${ }^{1}$, Mika Yamauchi ${ }^{1}$, \\ Naotake Yamauchi ${ }^{2,3}$, Riruke Maruyama ${ }^{2}$ and Keizo Kanasaki ${ }^{1}$
}

\begin{abstract}
Background: Thyroid crisis is a life-threatening condition in thyrotoxic patients. Although differentiated thyroid cancer is one of the causes of hyperthyroidism, reports on thyroid crisis caused by thyroid cancer are quite limited. Here, we describe a case of thyroid crisis caused by metastatic thyroid cancer.

Case presentation: A 91-year-old woman was admitted to our hospital because of loss of appetite. Two years prior to this hospitalization, she presented with subclinical thyrotoxicosis and was diagnosed with histologically unidentified thyroid cancer with multiple metastases, and she refused aggressive medical interventions. On admission, she exhibited extreme thyrotoxicosis, and the presence of fever, severe tachycardia, impaired consciousness, and heart failure revealed the presence of thyroid crisis. All thyroid autoantibodies were negative. Multidisciplinary conservative treatment was initiated; however, she died on the fifth day after admission. Autopsy revealed the presence of primary anaplastic thyroid carcinoma and multiple metastatic foci arising from follicular thyroid carcinoma. Both primary and metastatic follicular thyroid carcinoma likely induced thyrotoxicosis, which could have been exacerbated by anaplastic thyroid carcinoma.
\end{abstract}

Conclusions: Even though the trigger of thyroid crisis in this patient is not clear, the aggravated progression of her clinical course suggests that careful monitoring of thyroid hormones and appropriate intervention are essential for patients with thyroid cancer.

Keywords: Thyroid crisis, Follicular thyroid carcinoma, Anaplastic thyroid carcinoma, Metastasis

\section{Background}

Thyroid crisis is a life-threatening condition requiring emergency treatment in thyrotoxic patients $[1,2]$. Patients with thyroid crisis exhibit multiple organ failure induced by the disruption of haemodynamics due to excess thyroid hormone and have a mortality rate higher than $10 \%$ in Japan [1]. Graves' disease is the most common cause of both hyperthyroidism and thyroid crisis $[1,3]$. Often, individuals with thyroid crisis have triggers for the onset of thyroid crisis. Although differentiated thyroid cancer is one of the causes of hyperthyroidism, [4]

\footnotetext{
*Correspondence: mnotsu25@med.shimane-u.ac.jp

1 Department of Internal Medicine 1, Faculty of Medicine, Shimane University, 89-1 Enya-cho, Izumo, Shimane 693-8501, Japan

Full list of author information is available at the end of the article
}

reports on thyroid crisis caused by thyroid cancer are quite limited.

Here, we present a case of uncontrollable thyroid crisis caused by thyroid cancer with multiple metastases.

\section{Case presentation}

A 91-year-old woman was admitted to Shimane University Hospital because of loss of appetite. Two years prior to this hospitalization, at the age of 89 , computed tomography $(\mathrm{CT})$ scans incidentally revealed a $55 \mathrm{~mm}$ tumour in the right lobe of the thyroid gland, mediastinal lymphadenopathy, and multiple pulmonary nodules. Fine-needle aspiration cytology demonstrated nuclear grooves in the tumour, which formed small follicular structures, but intranuclear cytoplasmic inclusion was not observed.

(c) The Author(s). 2021 Open Access This article is licensed under a Creative Commons Attribution 4.0 International License, which permits use, sharing, adaptation, distribution and reproduction in any medium or format, as long as you give appropriate credit to the original author(s) and the source, provide a link to the Creative Commons licence, and indicate if changes were made. The images or other third party material in this article are included in the article's Creative Commons licence, unless indicated otherwise in a credit line to the material. If material is not included in the article's Creative Commons licence and your intended use is not permitted by statutory regulation or exceeds the permitted use, you will need to obtain permission directly from the copyright holder. To view a copy of this licence, visit http://creativecommons.org/licenses/by/4.0/ The Creative Commons Public Domain Dedication waiver (http://creativecommons.org/publicdomain/zero/1.0/) applies to the data made available in this article, unless otherwise stated in a credit line to the data. 
Cytology could not specify the type of thyroid cancer. Due to her age, she did not wish to receive aggressive management to treat the histologically unidentified thyroid cancer with multiple metastases. Her thyroid-stimulating hormone (TSH) was under the detection limit, and she had subclinical thyrotoxicosis (free thyroxine (FT4) 1.0 ng/dL) with high thyroglobulin (Tg) levels (Fig. 1). She did not have any symptoms. We discussed the risks and benefits associated with anti-thyroid treatment with her and her family, and they chose no specific treatment for her thyrotoxicosis. Until 2 months prior to hospitalization, her condition was unremarkable. Two weeks before admission, however, she demonstrated overt thyrotoxicosis (free triiodothyronine (FT3) $9.2 \mathrm{pg} / \mathrm{mL}, \mathrm{FT} 4 \quad 2.4 \mathrm{ng} / \mathrm{dL}$, and FT3/FT4 ratio 3.8) without overt symptoms. She was prescribed potassium iodide (KI) (50 mg); however, her general status worsened to include loss of appetite. She was hospitalized to improve her general status and to treat thyrotoxicosis.

Six months after the thyroid tumour was diagnosed, she experienced a pathological left hip fracture due to bone metastasis. She also had a history of cerebral infarction treated with an antiplatelet drug. Her activities of daily living were generally suitable before the emergency admission.

Her height was $143 \mathrm{~cm}$, her body weight was $29.3 \mathrm{~kg}$, and her body mass index was $14.3 \mathrm{~kg} / \mathrm{m}^{2}$. The Glasgow coma scale score was E4V4M6. Her blood pressure was $167 / 100 \mathrm{mmHg}$, pulse rate was $160 / \mathrm{min}$, body temperature was $38.4{ }^{\circ} \mathrm{C}$, oxygen saturation $\left(\mathrm{SpO}_{2}\right)$ was
97\% (room air), and respiratory rate was $26 / \mathrm{min}$. Her anterior neck was markedly swollen without overt pain. The other physical findings were unremarkable except for mild pitting oedema of the bilateral lower extremities.

The laboratory findings on admission are shown in Table 1. She had extreme thyrotoxicosis above the sensitivity limits $(\mathrm{TSH}<0.003 \mu \mathrm{U} / \mathrm{mL}$, FT3 $>25 \mathrm{pg} / \mathrm{mL}$, FT4 $>$ $8 \mathrm{ng} / \mathrm{dL}$ ). The presence of fever, severe tachycardia, impaired consciousness, and heart failure suggested thyroid crisis. TSH receptor antibody and Hashimoto thyroiditisrelated antibodies were all negative, suggesting that her thyrotoxicosis was caused by thyroid cancer or destructive thyroiditis. A CT scan identified an enlarged thyroid tumour and metastases (Fig. 2). Ultrasound revealed diffuse enlargement of the right lobe of the thyroid gland with increased blood flow (Fig. 3). An electrocardiogram showed severe sinus tachycardia without atrial fibrillation. Echocardiography revealed diffuse asynergy, suggesting takotsubo cardiomyopathy, likely due to the aberrant sympatho-adrenergic activation induced by thyrotoxicosis. The ejection fraction was $22 \%$. The presence of infection was excluded by physical examination, CT images acquired at the time of hospitalization and only minor elevation of an inflammatory marker. Human chorionic gonadotropin (HCG)-induced hyperthyroidism was also excluded.

Despite treatment with KI, her thyrotoxicosis worsened. Considering possible augmentation of her thyrotoxicosis by the administered iodide, the KI was discontinued.

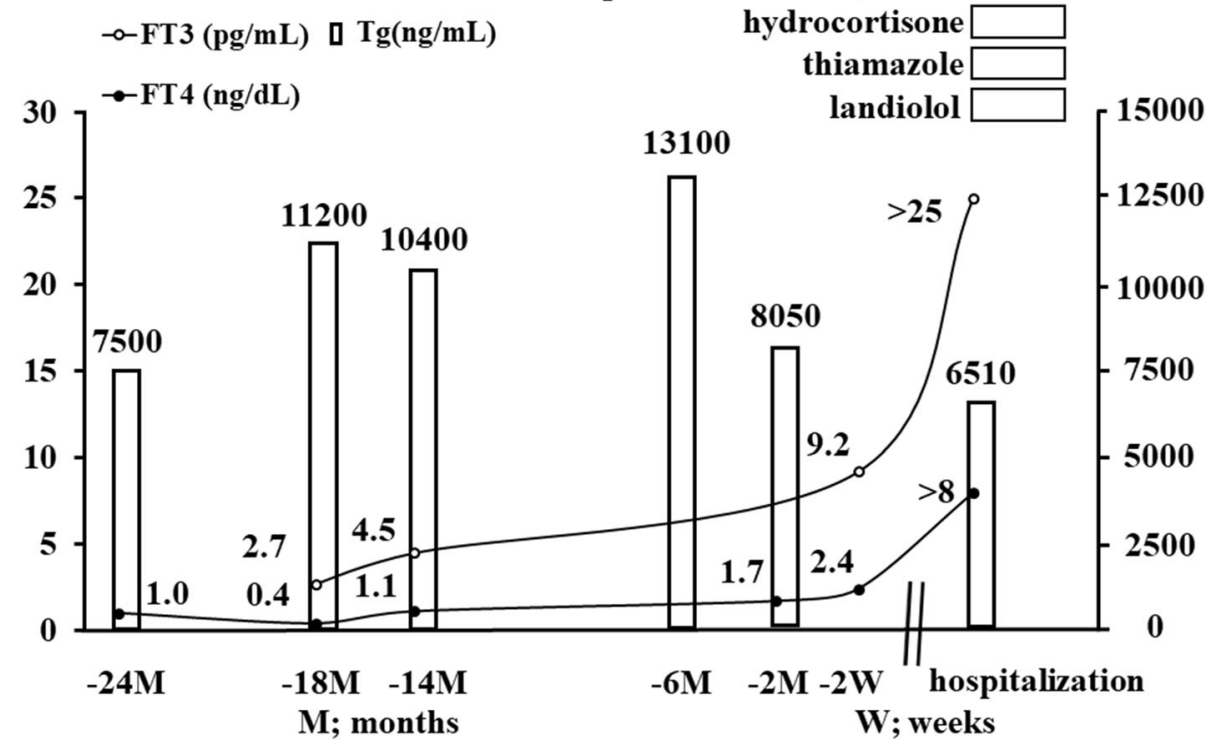

Fig. 1 Clinical course. When the patient was diagnosed with a thyroid tumour, her TSH was under the detection limit, and her thyroid hormone levels were normal; she had subclinical thyrotoxicosis. Her thyroid hormones worsened gradually until 2 weeks before admission; however, thyrotoxicosis rapidly deteriorated in the last 2 weeks. She also had a high Tg level at the first visit, which peaked 2 months before admission and then decreased 
Table 1 Baseline laboratory data

\begin{tabular}{|c|c|c|}
\hline Parameter & Observed & Reference range \\
\hline \multicolumn{3}{|c|}{ Venous blood gas analyses } \\
\hline $\mathrm{pH}$ & 7.28 & $7.35-7.45$ \\
\hline $\mathrm{pCO}_{2}, \mathrm{mmHg}$ & 34 & $35-48$ \\
\hline $\mathrm{HCO}_{3}{ }^{-}, \mathrm{mEq} / \mathrm{L}$ & 15 & $21-28$ \\
\hline lactic acid, mg/dL & 22 & $4.5-13.5$ \\
\hline \multicolumn{3}{|l|}{ Urinalysis } \\
\hline $\mathrm{pH}$ & 6.0 & $4.5-7.5$ \\
\hline blood & \pm & - \\
\hline protein & $2+$ & - \\
\hline ketone & $2+$ & - \\
\hline $\mathrm{I} / \mathrm{Cr}, \mu \mathrm{g} / \mathrm{gCr}$ & 27,120 & $200-1000$ \\
\hline \multicolumn{3}{|l|}{ Complete blood count } \\
\hline $\mathrm{WBC}, / \mu \mathrm{L}$ & 12,730 & $3300-8600$ \\
\hline Neutro, \% & 87 & $40-75$ \\
\hline $\mathrm{Hb}, \mathrm{g} / \mathrm{dL}$ & 9.9 & $11.6-14.8$ \\
\hline $\mathrm{Plt}, / \mu \mathrm{L}$ & $12.0 \times 10^{4}$ & $15.8-34.8 \times 10^{4}$ \\
\hline \multicolumn{3}{|l|}{ Serum characteristics } \\
\hline Alb, g/dL & 3.4 & $4.1-5.1$ \\
\hline T-Bil, mg/dL & 0.7 & $0.4-1.5$ \\
\hline AST, IU/L & 26 & $13-30$ \\
\hline ALT, IU/L & 28 & $7-23$ \\
\hline $\mathrm{LDH}, \mathrm{IU} / \mathrm{L}$ & 193 & $124-222$ \\
\hline ALP, IU/L & 152 & $106-322$ \\
\hline CK, IU/L & 93 & $41-153$ \\
\hline CK-MB, ng/mL & 10.6 & $<3.7$ \\
\hline $\mathrm{TNI}, \mathrm{ng} / \mathrm{mL}$ & 1.09 & $<0.04$ \\
\hline T-chol, mg/dL & 95 & $142-248$ \\
\hline $\mathrm{HbA} 1 \mathrm{c}, \%$ & 5.3 & $4.9-6.0$ \\
\hline BUN, mg/dL & 28 & $8-20$ \\
\hline $\mathrm{Cr}, \mathrm{mg} / \mathrm{dL}$ & 0.54 & $0.46-0.79$ \\
\hline $\mathrm{Na}, \mathrm{mEq} / \mathrm{L}$ & 142 & 138-145 \\
\hline $\mathrm{K}, \mathrm{mEq} / \mathrm{L}$ & 4.1 & $3.6-4.8$ \\
\hline $\mathrm{Cl}, \mathrm{mEq} / \mathrm{L}$ & 110 & $101-108$ \\
\hline $\mathrm{cCa}, \mathrm{mg} / \mathrm{dL}$ & 8.9 & $8.8-10.1$ \\
\hline $\mathrm{CRP}, \mathrm{mg} / \mathrm{dL}$ & 2.4 & $<0.03$ \\
\hline $\mathrm{PCT}, \mathrm{ng} / \mathrm{mL}$ & 0.06 & $<0.50$ \\
\hline $\mathrm{BNP}, \mathrm{pg} / \mathrm{mL}$ & 2796 & $<20$ \\
\hline $\mathrm{FT} 3, \mathrm{pg} / \mathrm{mL}$ & $>25$ & $2.1-3.8$ \\
\hline $\mathrm{FT} 4, \mathrm{ng} / \mathrm{dL}$ & $>8.0$ & $0.8-1.5$ \\
\hline $\mathrm{TSH}, \mu \mathrm{U} / \mathrm{mL}$ & $<0.003$ & $0.50-3.00$ \\
\hline TRAb, IU/L & $<0.9$ & $<2.0$ \\
\hline TSAb, \% & 114 & $<120$ \\
\hline $\mathrm{Tg}-\mathrm{Ab}, \mathrm{IU} / \mathrm{mL}$ & $<5.0$ & $<5.0$ \\
\hline TPO-Ab, IU/mL & $<3.0$ & $<3.0$ \\
\hline
\end{tabular}

Table 1 Baseline laboratory data (Continued)

\begin{tabular}{|c|c|c|}
\hline arameter & bserved & neter \\
\hline $\mathrm{Tg}, \mathrm{n}$ & 10 & 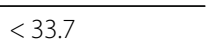 \\
\hline HCG, & & \\
\hline \multicolumn{3}{|c|}{ 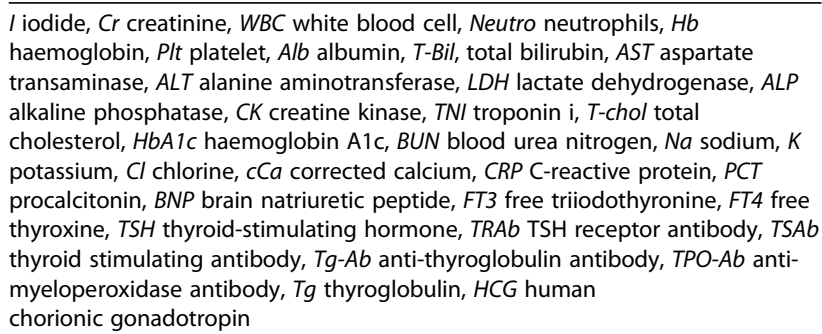 } \\
\hline
\end{tabular}

Treatment with intravenous hydrocortisone and oral thiamazole was initiated; however, due to her severe illness, the oral administration of thiamazole was not possible. The maximum dose of landiolol also failed to manage her tachycardia. Her condition deteriorated progressively, and she died on the fifth day of hospitalization.

After a discussion with her family, an autopsy was performed.

\section{$<$ Thyroid> $110 \mathrm{~g}, 7.6 \times 6.4 \times 3.0 \mathrm{~cm}$}

The thyroid was slightly hard and was weakly adhered to the trachea (Fig. 4). The tumour invaded the sternothyroid muscle, lymph nodes, and veins over the thyroid capsule. The cut surface showed a white solid mass with central haemorrhagic necrosis. The histological images revealed mainly formed nodules with thyroid follicles of various sizes invading the surrounding tissues, but they were mixed with atypical spindle tumour cells proliferating solidly without follicles (Fig. 5). After immunostaining, the spindle tumour cells were positive for cytokeratin AE1/AE3, CAM5.2 and paired box gene 8 (PAX8) and negative for epithelial membrane antigen (EMA), Tg, carcinoembryonic antigen (CEA), thyroid transcription factor-1 (TTF-1), and p53. Based on these findings, she was diagnosed with anaplastic thyroid carcinoma (ATC) arising from follicular thyroid carcinoma (FTC).

\section{<Other organs>}

The FTC filtrated the trachea. There were well-defined white lesions in both lungs, which were histologically metastases of FTC (Fig. 6). In addition, metastases were also observed in the hilar and superior mediastinal lymph nodes. No anaplastic cancer tissue was found in the metastatic lesions, which all showed findings of FTC. The ascending colon cancer that had been found before her death was moderately differentiated tubular adenocarcinoma invading the subserosal tissue. However, the histological and immunohistochemical features of this tumour were completely different from those of thyroid 
A

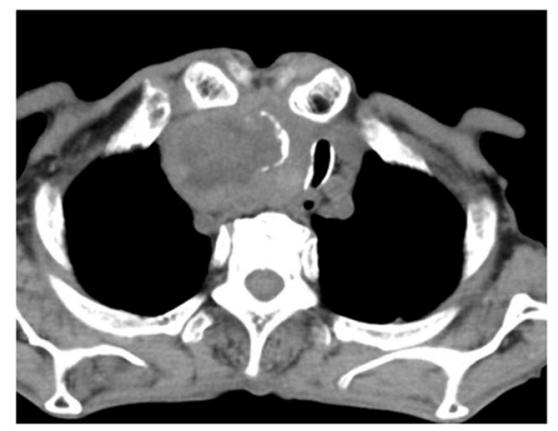

C

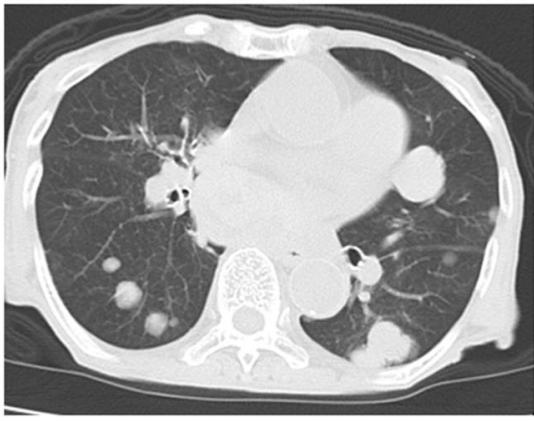

B

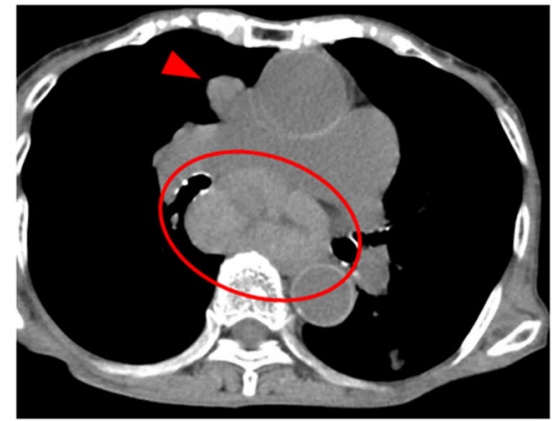

D

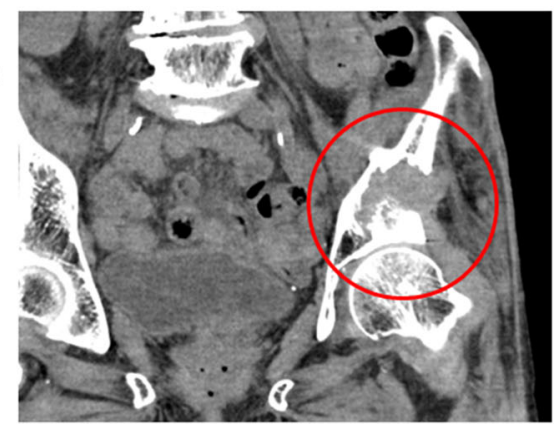

Fig. 2 Computed tomography scan. A: The thyroid was markedly swollen with calcification. Tracheal deviation was identified. B: The hilar and mediastinal lymph nodes were swollen. C: Multiple nodules were identified in both lungs. D: A pathological left hip fracture was identified

cancer. No infarction in the cardiac wall or obstruction in the coronary arteries was observed.

\section{Discussion and conclusions}

We reported a case of thyroid crisis likely caused by metastatic thyroid cancer. Multidisciplinary conservative treatment was not effective for her illness, and she died on the fifth day of hospitalization. The autopsy revealed the presence of primary ATC arising from FTC and multiple FTC metastases.
The Japan Thyroid Association has proposed diagnostic criteria for thyroid crisis [2]. The presence of thyrotoxicosis with elevated levels of FT3 or FT4 is a prerequisite for diagnosis. Patients with thyroid crisis have central nervous system manifestations, fever, tachycardia, congestive heart failure, and gastrointestinal/hepatic manifestations. Our patient displayed all of these parameters except for gastrointestinal/hepatic manifestations, so her symptoms were consistent with the diagnosis of thyroid crisis.

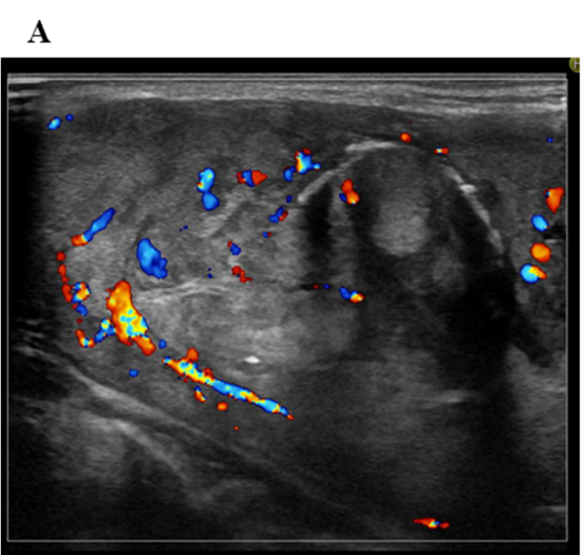

B

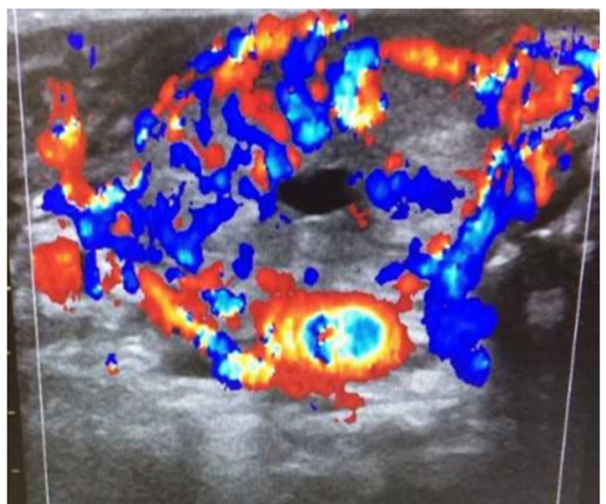

Fig. 3 Thyroid ultrasonography. A Two years before hospitalization. A large tumour was revealed in the right lobe with calcification and slight blood flow. B At the time of hospitalization. Diffuse enlargement of the right lobe with increased blood flow was revealed 


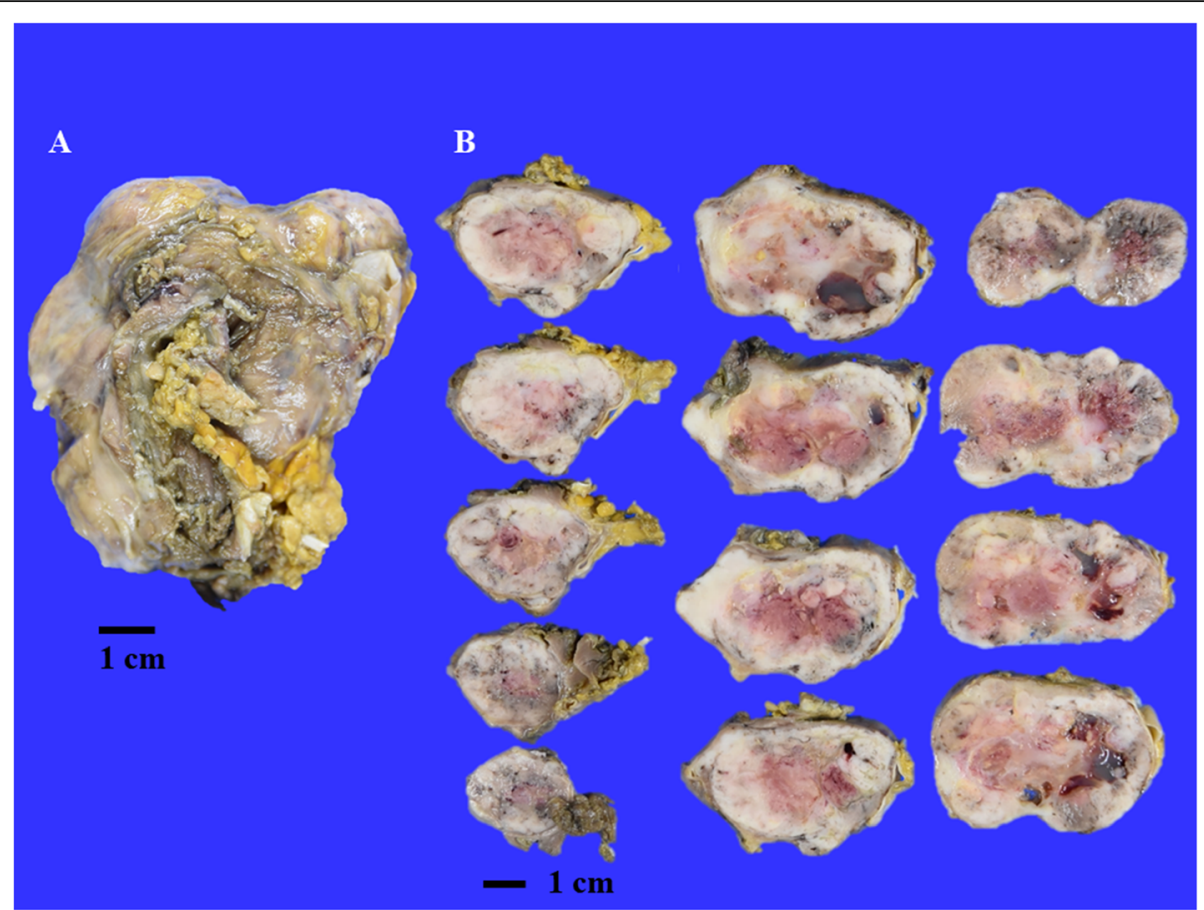

Fig. 4 Gross image of the thyroid. A The thyroid weighed $110 \mathrm{~g}$ and was $7.6 \times 6.4 \times 3.0 \mathrm{~cm}$ in size. The thyroid was slightly hard. B The cut surface of thyroid showed a white solid mass with central haemorrhagic necrosis

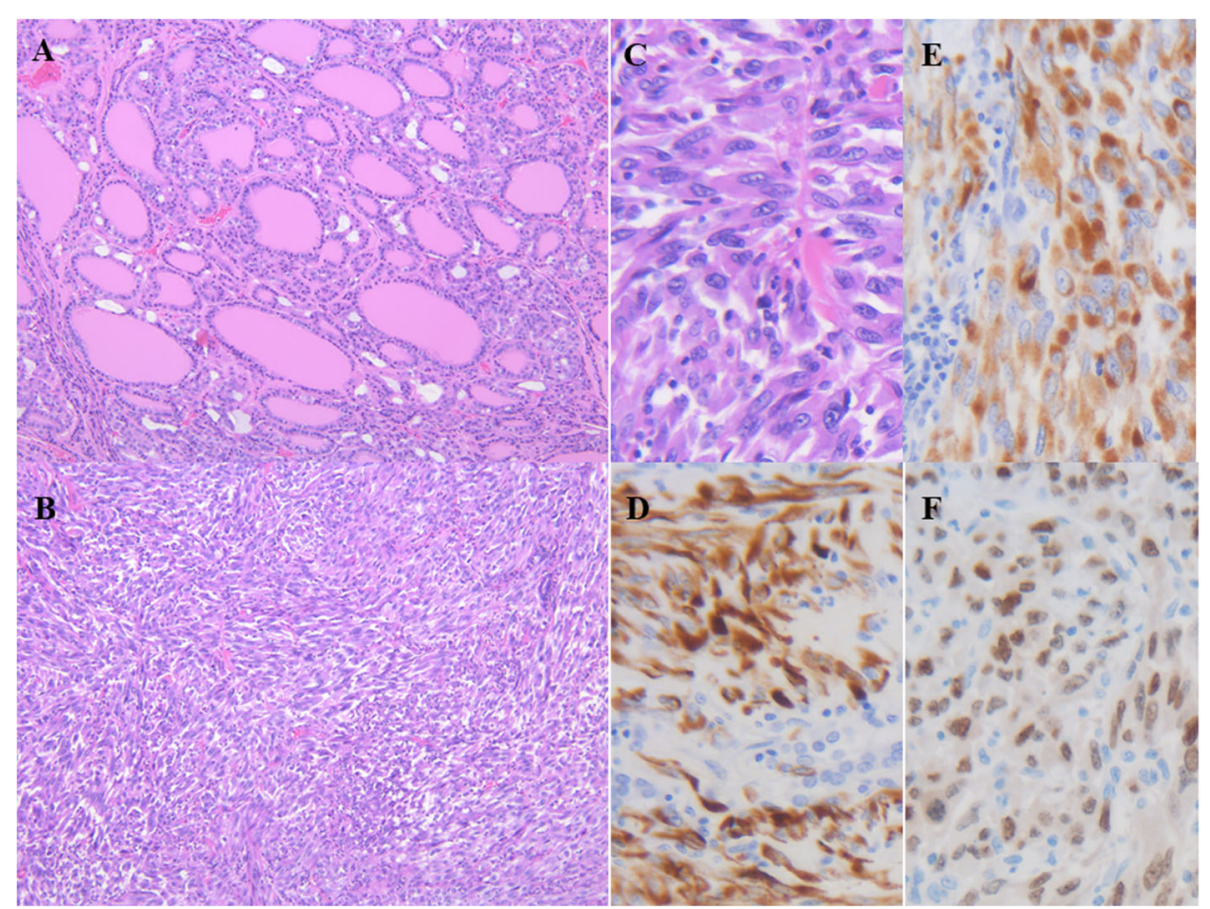

Fig. 5 Microscopic image of the thyroid. A Nodules with thyroid follicles of various sizes invading the surrounding tissues were mainly observed (hematoxylin and eosin, low magnification). B Atypical spindle tumour cells proliferating solidly without follicles were also observed (hematoxylin and eosin, low magnification). C Enlargement of the image shown in B (hematoxylin and eosin, high magnification). After immunostaining, the spindle tumour cells were positive for cytokeratin AE1/AE3 (D), CAM5.2 (E) and PAX8 (F) (high magnification) 


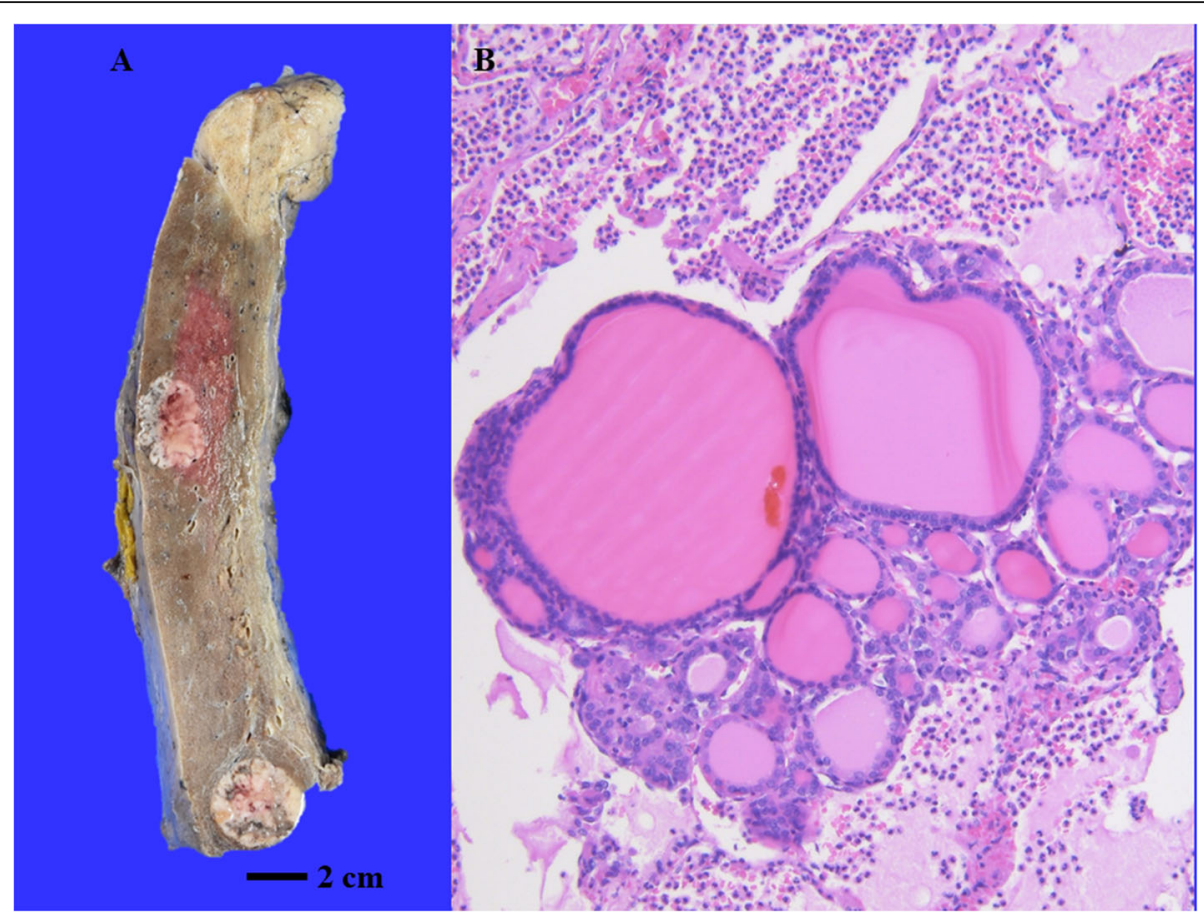

Fig. 6 Pathological findings of left lung. A There were well-defined white lesions in left lung. B Follicles of various sizes were observed and were considered to be metastases of FTC. No anaplastic cancer tissue was found in the metastatic lesions, which all showed findings of FTC (hematoxylin and eosin, low magnification)

In Japan, the primary cause of thyrotoxicosis among patients with thyroid crisis is Graves' disease, followed by destructive thyroiditis [1]. The potential trigger of thyroid crisis has been proven in $70 \%$ of patients. The most common trigger of thyroid crisis was the irregular use or discontinuation of antithyroid medication, and the second was infection. Other minor triggers are also known, such as diabetic ketoacidosis, severe emotional stress, trauma, surgery, radioiodine therapy, and pregnancy/delivery $[1,2]$ Among the causes of thyrotoxicosis, Graves' disease was excluded as she was negative for TSH receptor antibody. She had displayed prolonged thyrotoxicosis for 2 years before hospitalization; her clinical course was not typical for destructive thyroiditis, such as subacute thyroiditis and painless thyroiditis. In addition, the FT3/FT4 ratio is lower in destructive thyroiditis than in Graves' disease, and several studies have shown that the optimal FT3/FT4 ratio cut-off value is $2.8-3.0[5,6]$. In the present case, the FT3/FT4 ratio was elevated at the time of the first diagnosis of overt thyrotoxicosis. These findings suggested that the thyrotoxicosis in this case was not due to destructive thyroiditis. Thus, most likely, thyroid cancer induced her thyroid crisis; however, the trigger is not completely clear.
Hyperfunctioning thyroid cancer can absorb iodine and synthesize/release thyroid hormone [4]. Activating mutations in TSH receptor genes activate the intracellular cyclic adenosine monophosphate (cAMP) cascade, which is the most considerable cause of hyperthyroidism due to thyroid cancer [7]. Among hyperfunctioning thyroid cancers, FTC has been shown to have a markedly higher prevalence $(46.5 \%$ for primary and $71.4 \%$ for metastatic disease) than other types [4]. The Surveillance, Epidemiology and End Results (SEER) cancer registry (1974-2013) indicates that FTC only accounts for $10.8 \%$ of all thyroid cancers [8]. These data indicate that the proportion of FTC among hormone-producing thyroid cancers is high. Additionally, the tumour burden of hyperfunctioning thyroid cancer is remarkably larger $(4.25 \pm 2.12 \mathrm{~cm})$ [4]. By comparison, the SEER cancer registry programme indicates that $28.6 \%$ of thyroid carcinomas are $\leq 1.0 \mathrm{~cm}$ in size, $26.0 \%$ are $>1.0$ to $\leq 2.0 \mathrm{~cm}$, $23.0 \%$ are $>2.0$ to $\leq 4.0 \mathrm{~cm}$, and $9.6 \%$ are $>4.0 \mathrm{~cm}$ [8]. Furthermore, in cases of metastatic hyperfunctioning thyroid cancers, tumour metastases are widespread or large [4]. Large primary or metastatic tumours synthesize excessive thyroid hormones, resulting in the onset of hyperthyroidism. In the present case of FTC, the primary tumour was large in size, and the metastases were widespread, consistent with previous reports. The 
patient had subclinical thyrotoxicosis at the time of the first diagnosis. Hormone production by both/either primary and/or metastatic FTC lesions would cause/later augment her thyrotoxicosis.

The effect of KI on hyperthyroidism in thyroid cancer patients has not yet been established, although a former report indicated the beneficial effects of inorganic iodine used in combination with antithyroid drugs and glucocorticoids on thyroid cancer-associated hyperthyroidism $[9,10]$. KI in combination with antithyroid drugs is generally the gold standard in thyroid crisis cases [1]. However, surprisingly, little is known about whether KI is effective in thyroid cancer patients via the WolffChaikoff effect. The molecular mechanisms of the Wolff-Chaikoff effect have not been established [11, 12]. Most research analysing the direct effects of iodine was performed on hypophysectomized animals given a standard dose of TSH, essentially regulating thyroid activity [13]. Therefore, the effects of KI in patients with diminished levels of either TSH or thyroid-stimulating antibody, such as the presented patient, are absolutely unknown, and we could not even obtain sufficient information from preclinical studies. Taken together, whether KI should be used in thyroid cancer patients with hyperthyroidism needs to be established by further investigations, and we may need to consider the harmful influence of iodine in cancer patients due to thyroid hormone secretion and potential crisis.

To the best of our knowledge, there have been only five reports about thyroid crisis due to thyroid cancer (Table 2) $[9,10,14-16]$. All were due to differentiated thyroid cancer, including papillary thyroid carcinoma (PTC) (one case), a follicular variant of PTC (three cases) and FTC (two cases, including our case). Metastases were found in five cases, including our case. Most patients had triggers, and three patients had Graves' disease, which is similar to the general characteristics of patients with thyroid crisis [1]. The mortality rate was also high.

Thyroid crisis associated with the presence of mixed FTC and ATC has never been reported. ATC proliferates rapidly and has a very poor prognosis [17]. There are several reports of patients with thyrotoxicosis due to ATC [18]. Compared to other subtypes of thyroid cancer, ATC rarely causes thyrotoxicosis or thyroid crisis. ATC may cause thyrotoxicosis through two mechanisms: leakage of thyroid hormone into the bloodstream via the mechanical destruction of thyrocytes, or hyperfunctioning metastatic tumours $[19,20]$. In the present case, the patient's symptoms rapidly deteriorated in the last 2 weeks before admission. During the clinical course, $\mathrm{Tg}$ peaked 6 months before admission then decreased, and her urinary iodine excretion was very high on admission. These data suggest that the ATC developed from the transformation of the coexisting FTC. Fozzatti et al. showed that the secretome of cancer-associated fibroblasts activated by ATC cell-derived conditioned media promoted FTC proliferation and invasion [21]. Based on this report, ATC facilitated FTC proliferation and metastases in the present case, promoting thyrotoxicosis severity.

In summary, we reported a case of thyroid crisis due to metastatic thyroid cancer. The autopsy revealed the presence of ATC arising from FTC and multiple metastases composed of FTC. Her thyrotoxicosis was caused by both/either primary and/or metastatic FTC lesions and perhaps facilitated by ATC. Although the trigger of her thyroid crisis was not identified, the aggravated progression of her clinical course suggests that careful monitoring of thyroid hormones and appropriate intervention are essential for the management of patients with thyroid cancer.

Table 2 Reported cases of thyroid crisis due to thyroid cancer

\begin{tabular}{|c|c|c|c|c|c|c|c|c|c|}
\hline No. & Age & Sex & Pathology & Metastasis & Trigger & Outcome & Graves' disease & Remarks & Refs. \\
\hline 1 & 20 & $\mathrm{~F}$ & PTC & no & $\begin{array}{l}\text { 1) pregnancy? } \\
\text { 2) delivery }\end{array}$ & alive & $\begin{array}{l}+ \\
\text { propylthiouracil }\end{array}$ & $\begin{array}{l}\text { two episodes of thyroid crisis } \\
\text { 1) at } 25 \text { weeks gestation } \\
\text { 2) at } 2 \text { weeks post-partum }\end{array}$ & 14 \\
\hline 2 & 71 & $\mathrm{~F}$ & FVPTC & bone, lung & $\begin{array}{l}\text { contrast-enhanced } \\
\mathrm{CT} \\
\text { incisional biopsy }\end{array}$ & death & $\begin{array}{l}+ \\
\text { no treatment }\end{array}$ & & 9 \\
\hline 3 & 68 & M & FVPTC & bone & total thyroidectomy & alive & $\begin{array}{l}+ \\
\text { thiamazole }\end{array}$ & & 15 \\
\hline 4 & 66 & $\mathrm{~F}$ & FVPTC & bone, lung & total thyroidectomy & death & - & & 10 \\
\hline 5 & 54 & $M$ & FTC & bone & $\begin{array}{l}\text { burn injury } \\
\text { surgery }\end{array}$ & death & unknown & $\begin{array}{l}\text { post total thyroidectomy and } \\
\text { treatment with radioactive } \\
\text { iodine before } 14 \text { months }\end{array}$ & 16 \\
\hline 6 & 91 & $\mathrm{~F}$ & $\begin{array}{l}\text { FTC } \\
\text { ATC }\end{array}$ & bone, lung & unknown & death & - & $\begin{array}{l}\text { primary ATC arising from FTC } \\
\text { and multiple FTC metastases }\end{array}$ & our case \\
\hline
\end{tabular}




\section{Abbreviations}

$\mathrm{CT}$ : Computed tomography; TSH: Thyroid-stimulating hormone; FT4: Free thyroxine; Tg: Thyroglobulin; FT3: Free triiodothyronine; Kl: Potassium iodide; HCG: Human chorionic gonadotropin; PAX8: Paired box gene 8; EMA: Epithelial membrane antigen; CEA: Carcinoembryonic antigen; TTF1: Thyroid transcription factor-1; ATC: Anaplastic thyroid carcinoma; FTC: Follicular thyroid carcinoma; CAMP: Cyclic adenosine monophosphate; PTC: Papillary thyroid carcinoma

\section{Acknowledgements}

Not applicable.

\section{Authors' contributions}

$K T, M N, N A$, and ST managed the patient as the attending physicians. M Yamamoto, M Yamauchi, and KK evaluated the medical management strategies. NY and RM performed the autopsy. KT, MN, RM, and KK wrote the paper. All authors read and approved the final manuscript.

\section{Funding}

Not applicable.

\section{Availability of data and materials}

The datasets used and/or analysed during the current study are available from the corresponding author on reasonable request.

\section{Declarations}

\section{Ethics approval and consent to participate}

Not applicable.

\section{Consent for publication}

Consent for publication was obtained from all individual participants included in the study.

\section{Competing interests}

The authors declare that they have no competing interests in this paper.

\section{Author details}

'Department of Internal Medicine 1, Faculty of Medicine, Shimane University, 89-1 Enya-cho, Izumo, Shimane 693-8501, Japan. ²Department of Pathology, Faculty of Medicine, Shimane University, 89-1 Enya-cho, Izumo, Shimane 693-8501, Japan. ${ }^{3}$ Department of Pathology, Faculty of Medicine, University of Toyama, 2630 Sugitani, Toyama, Toyama 930-0194, Japan.

Received: 30 March 2021 Accepted: 15 October 2021

Published online: 24 October 2021

\section{References}

1. Akamizu T. Thyroid Storm: A Japanese Perspective. Thyroid. 2018;28(1):3240. https://doi.org/10.1089/thy.2017.0243.

2. Akamizu T, Satoh T, Isozaki O, Suzuki A, Wakino S, Iburi T, et al. Diagnostic criteria, clinical features, and incidence of thyroid storm based on nationwide surveys. Thyroid. 2012;22(7):661-79. https://doi.org/10.1089/thy.2 011.0334 .

3. De Leo S, Lee SY, Braverman LE. Hyperthyroidism. Lancet. 2016;388(10047): 906-18. https://doi.org/10.1016/S0140-6736(16)00278-6.

4. Liu J, Wang Y, Da D, Zheng M. Hyperfunctioning thyroid carcinoma: a systematic review. Mol Clin Oncol. 2019;11:535. https://doi.org/10.3892/ mco.2019.1927.

5. Tura Bahadır Ç, Yılmaz M, Kılıçkan E. Free triiodothyronine to free thyroxine ratio in the differential diagnosis of thyrotoxicosis and hyperthyroidism: a retrospective study. Int J Clin Pract. 2021;75(5):e14003. https://doi.org/1 $0.1111 /$ ijcp. 14003

6. Yoshimura Noh J, Momotani N, Fukada S, Ito K, Miyauchi A, Amino N. Ratio of serum free triiodothyronine to free thyroxine in Graves' hyperthyroidism and thyrotoxicosis caused by painless thyroiditis. Endocr J. 2005:52(5):53742. https://doi.org/10.1507/endocrj.52.537.

7. Gozu H, Avsar M, Bircan R, Sahin S, Ahiskanali R, Gulluoglu B, et al. Does a Leu 512 Arg thyrotropin receptor mutation cause an autonomously functioning papillary carcinoma? Thyroid. 2004;14(11):975-80. https://doi. org/10.1089/thy.2004.14.975.
8. Lim H, Devesa SS, Sosa JA, Check D, Kitahara CM. Trends in thyroid Cancer incidence and mortality in the United States, 1974-2013. JAMA. 2017; 317(13):1338-48. https://doi.org/10.1001/jama.2017.2719.

9. Pinto A, Drake T, Cayci Z, Burmeister LA. Thyroid storm with coma in a patient with metastatic thyroid carcinoma and graves disease: won the Battle but lost the war. AACE Clin Case Rep. 2019;5:e7. https://doi.org/10.41 58/ACCR-2018-0262.

10. Gardner D, Ho SC. A rare cause of hyperthyroidism: functioning thyroid metastases. Case Reports. 2014, 2014:bcr2014206468.

11. Markou K, Georgopoulos N, Kyriazopoulou V, Vagenakis AG. lodine-induced hypothyroidism. Thyroid. 2001;11(5):501-10. https://doi.org/10.1089/105072 501300176462.

12. Leung AM, Braverman LE. Consequences of excess iodine. Nat Rev Endocrinol. 2014;10(3):136-42. https://doi.org/10.1038/nrendo.2013.251.

13. Solis-S JC, Villalobos P, Orozco A, Delgado G, Quintanar-Stephano A, GarciaSolis $\mathrm{P}$, et al. Inhibition of intrathyroidal dehalogenation by iodide. J Endocrinol. 2011;208(1):89-96. https://doi.org/10.1677/JOE-10-0300.

14. Tewari K, Balderston KD, Carpenter SE, Major CA. Papillary thyroid carcinoma manifesting as thyroid storm of pregnancy: case report. Am J Obstet Gynecol. 1998;179(3):818-9. https://doi.org/10.1016/S0002-9378(98)70091-2.

15. Folkestad L, Brandt F, Brix T, Vogsen M, Bastholt L, Grupe P, et al. Total thyroidectomy for thyroid Cancer followed by thyroid storm due to thyrotropin receptor antibody stimulation of metastatic thyroid tissue. Eur Thyroid J. 2017;6(5):276-80. https://doi.org/10.1159/000479061.

16. Naito Y, Sone T, Kataoka K, Sawada M, Yamazaki K. Thyroid storm due to functioning metastatic thyroid carcinoma in a burn patient. Anesthesiology. 1997;87(2):433-5. https://doi.org/10.1097/00000542-199708000-00034.

17. Cabanillas ME, McFadden DG, Durante C. Thyroid cancer. Lancet. 2016; 388(10061):2783-95. https://doi.org/10.1016/S0140-6736(16)30172-6.

18. Daroszewski J, Paczkowska K, Jawiarczyk-Przybyłowska A, Bolanowski M, Jeleń M. Anaplastic thyroid carcinoma with rapid thyrotoxicosis - a case report and the literature review. Endokrynol Pol. 2018;69(1):28-31. https:// doi.org/10.5603/EP.a2018.0010.

19. Basaria S, Udelsman R, Tejedor-Sojo J, Westra WH, Krasner AS. Anaplastic pseudothyroiditis. Clin Endocrinol. 2002;56(4):553-5. https://doi.org/10.1046/ j.1365-2265.2002.01495.x

20. Phillips JS, Pledger DR, Hilger AW. Rapid thyrotoxicosis in anaplastic thyroid carcinoma. J Laryngol Otol. 2007;121(7):695-7. https://doi.org/10.1017/ S0022215106005330.

21. Fozzatti L, Alamino VA, Park S, Giusiano L, Volpini X, Zhao L, et al. Interplay of fibroblasts with anaplastic tumor cells promotes follicular thyroid cancer progression. Sci Rep. 2019;9(1):8028. https://doi.org/10.1 038/s41598-019-44361-6.

\section{Publisher's Note}

Springer Nature remains neutral with regard to jurisdictional claims in published maps and institutional affiliations.

Ready to submit your research? Choose BMC and benefit from:

- fast, convenient online submission

- thorough peer review by experienced researchers in your field

- rapid publication on acceptance

- support for research data, including large and complex data types

- gold Open Access which fosters wider collaboration and increased citations

- maximum visibility for your research: over $100 \mathrm{M}$ website views per year

At BMC, research is always in progress.

Learn more biomedcentral.com/submissions 